\title{
Isentropic Cross-Tropopause Ozone Transport in the Northern Hemisphere
}

Ping Jing

Loyola University Chicago, pjing@luc.edu

D M. Cunnold

H J. Wang

E S. Yang

Follow this and additional works at: https://ecommons.luc.edu/ies_facpubs

Part of the Life Sciences Commons

\section{Recommended Citation}

Jing, P, DM Cunnold, HJ Wang, and ES Yang. "Isentropic Cross-Tropopause Ozone Transport in the Northern Hemisphere." Journal of the Atmospheric Sciences 61, 2003.

This Article is brought to you for free and open access by the Faculty Publications and Other Works by Department at Loyola eCommons. It has been accepted for inclusion in School of Environmental Sustainability: Faculty Publications and Other Works by an authorized administrator of Loyola eCommons. For more information, please contact ecommons@luc.edu. c) (i) () $\Theta$

This work is licensed under a Creative Commons Attribution-Noncommercial-No Derivative Works 3.0 License. (c) American Meteorological Society, 2003. 


\title{
Isentropic Cross-Tropopause Ozone Transport in the Northern Hemisphere
}

\author{
P. Jing, D. M. Cunnold, H. J. Wang, And E.-S. YAng \\ School of Earth and Atmosphere Sciences, Georgia Institute of Technology, Atlanta, Georgia
}

(Manuscript received 13 March 2003, in final form 27 November 2003)

\begin{abstract}
This paper investigates isentropic ozone exchange between the extratropical lower stratosphere and the subtropical upper troposphere in the Northern Hemisphere. The quantification method is based on the potential vorticity (PV) mapping of Stratospheric Aerosol and Gas Experiment (SAGE)-II ozone measurements and contour advection calculations using the NASA Goddard Space Center Data Assimilation Office (DAO) analysis for the year 1990. The magnitude of the annual isentropic stratosphere-to-troposphere ozone flux is calculated to be approximately twice the flux that is directed from the troposphere into the stratosphere. The net effect is that $\sim 46 \times 10^{9} \mathrm{~kg} \mathrm{yr}^{-1}$ of ozone are transferred quasi horizontally from the extratropical lower stratosphere into the subtropical upper troposphere between the isentropic surfaces of 330 and $370 \mathrm{~K}$. The estimated monthly ozone fluxes show that the isentropic cross-tropopause ozone transport is stronger in summer/fall than in winter/ spring, and this seasonality is more obvious at the upper three levels (i.e., 345, 355, and $365 \mathrm{~K}$ ) than at $335 \mathrm{~K}$. The distributions of the estimated monthly ozone fluxes indicate that the isentropic stratosphere-to-troposphere ozone exchange is associated with wave breaking and occurs preferentially over the eastern Atlantic Ocean and northwest Africa in winter and over the Atlantic and Pacific Oceans in summer.
\end{abstract}

\section{Introduction}

Historically, transport of ozone from the stratosphere was thought of as the only major source of tropospheric ozone (e.g., Junge 1962; Danielson 1968). While increasing appreciation has been paid to the importance of photochemical production and destruction of tropospheric ozone (e.g., Crutzen 1973; Chameides and Walker 1973; Liu et al. 1987; Davis et al. 1996; Levy et al. 1997), studies indicate that stratosphere-troposphere exchange (STE) still contributes $20 \% \sim 50 \%$ of tropospheric ozone globally (Follows and Austin 1992; Roelofs and Lelieveld 1997; Lelieveld and Dentener 2000).

A variety of methods have been used to estimate the ozone fluxes from the stratosphere to the troposphere: for example, the correlation between the fluxes of $\mathrm{O}_{3}$ and other variables like potential vorticity (PV; Gidel and Shapiro 1980) and $\mathrm{N}_{2} \mathrm{O}$ (Murphy and Fahey 1994); the correlation between column ozone and column PV above the tropopause (Olsen et al. 2002, 2003); global three-dimensional chemical-transport modeling (e.g., Crutzen 1995; Müller and Brasseur 1995; Levy et al. 1997; Lelieveld and Dentener 2000); and statistical analysis of the frequency of tropopause folding (Beekmann et al. 1997). Estimates of stratosphere-to-troposphere ozone transport vary from $400 \sim 1400 \times 10^{9} \mathrm{~kg} \mathrm{yr}^{-1}$

Corresponding author address: Dr. Derek M. Cunnold, 311 Ferst Drive, Atlanta, GA 30332-0340.

E-mail: cunnold@eas.gatech.edu
(Houghton et al. 2001). This wide range indicates that from a global perspective our understanding of the ozone STE is incomplete.

In estimating the STE, we are especially interested in the so-called middle world (Hoskins 1991), where isentropic surfaces intersect the tropopause, which is usually located in the lower stratosphere (LS) and upper troposphere (UT). According to Holton et al. (1995), in the middle world the STE of air and chemical species can be accomplished not only by vertical diabatic motions but also by irreversible mixing along isentropic surfaces. This quasi-horizontal isentropic exchange occurs on a time scale of days to weeks, while the vertical diabatic exchange occurs on a time scale of months (Chen 1995). Observational evidence has shown that transport on isentropic surfaces varies from large scale $(2000 \sim 3000 \mathrm{~km})$ to small scale $(<200 \mathrm{~km}$; Appenzeller et al. 1996). Wang et al. (1998a) provided observational evidence of the cross-tropopause ozone transport via isentropic processes based on measurements from the Stratospheric Aerosol and Gas Experiment (SAGE)-II. However, both conventional Eulerian and Lagrangian numerical methods have practical difficulties in representing the spatial complexity of the isentropic flow and at the same time keeping the computation manageable. Therefore, it is still uncertain how much stratospheric ozone is transported into the troposphere through the isentropic STE processes.

A recently developed Lagrangian technique, contour advection, has been shown to be able to resolve the 
continuous generation of small-scale structures in twodimensional isentropic flows (Norton 1994; Waugh and Plumb 1994; Baker and Cunnold 2001). Numerical methods based on contour advection have been used to quantify the isentropic fluxes of air mass (Dethof et al. 2000a) and water vapor (Dethof et al. 2000b) across the tropopause in the middle world. These results indicate that isentropic transport is potentially an important path for the STE of air and water vapor in the middle world and that such a process is strongest in summer. The aim of this paper is to estimate the cross-tropopause isentropic ozone fluxes by applying contour advection.

However, a big challenge is to obtain global ozone mixing ratio distributions with spatial and temporal resolutions comparable to those of the analyzed advecting wind fields. To solve this problem, this paper utilizes the relationship between the potential vorticity (PV) field and the ozone field, which have been noticed to be tightly correlated (e.g., Danielson 1968; Gidel and Shapiro 1980; Danielson et al. 1987; Morgenstern and Marenco 2000). Twelve monthly relationships between analyzed potential vorticities and ozone mixing ratios from SAGE II observations are derived on several isentropic surfaces. These monthly $\mathrm{PV}-\mathrm{O}_{3}$ relationships are then used to derive daily ozone distributions from daily analyzed PV maps. It is shown in section $4 \mathrm{a}$ of this paper that the $\mathrm{PV}-\mathrm{O}_{3}$ correlation is a convenient and effective way to obtain global ozone maps in the LS and UT.

Combining the contour advection technique and the ozone maps derived from the monthly $\mathrm{PV}-\mathrm{O}_{3}$ relationships, this paper estimates the monthly and annual isentropic ozone fluxes across the tropopause on four isentropic layers between 330 and $370 \mathrm{~K}$ in the Northern Hemisphere (NH) for the year 1990. The geographical distributions of the monthly ozone fluxes are also investigated and are shown to be associated with the locations of Rossby wave breaking identified in other studies (e.g., Postel and Hitchman 1999; Scott and Cammas 2002).

\section{Data}

The meteorological data source is the Data Assimilation Office (DAO) at National Aeronautics and Space Administration (NASA) Goddard Space Flight Center. They provide Goddard Earth Observing System (GEOS) assimilated products. At the time of this study GEOS-1 data for 1980 to 1993 were available; we have used data for 1990. The isobaric data are available 6-hourly (0000, 0600,1200 , and 1800 UTC) at 18 pressure levels (1000, 950, 900, 850, 800, 700, 600, 500, 400, 300, 250, 200, $150,100,70,50,30$, and $20 \mathrm{hPa}$ ) with a horizontal resolution of $2.0^{\circ}$ latitude by $2.5^{\circ}$ longitude (Schubert et al. 1993). We interpolated the data vertically from pressure surfaces onto 11 isentropic surfaces from 320 to $370 \mathrm{~K}$ at $5-\mathrm{K}$ resolution using the interpolation method in Edouard et al. (1997).
The ozone data are from the SAGE II measurements. SAGE II has been measuring stratospheric ozone profiles since October 1984. It provides up to 15 sunrise and 15 sunset profiles every $24 \mathrm{~h}$. Version-6.1 ozone retrievals are used in this study. The SAGE II V6.1 ozone mixing ratios below $20 \mathrm{~km}$ altitude have been shown to be more accurate than previous retrievals (Wang et al. 2002). The agreement between SAGE II V6.1 and ozonesonde data in the mean is approximately $10 \%$ or better down to the tropopause. In the region between $8 \mathrm{~km}$ altitude and $2 \mathrm{~km}$ below the tropopause, the SAGE ozone is approximately $30 \%$ low relative to the ozonesonde climatology (Wang et al. 2002).

\section{Approaches \\ a. Tropopause definition}

There are two conventional ways to define the tropopause: the thermal definition based on the lapse-rate criteria and the dynamical definition based on a PV threshold value. We use PV to define the tropopause in this study for two reasons: 1) the PV tropopause reflects the dynamical property differences between the stratosphere and troposphere better than the thermal tropopause; and 2) PV is conserved in isentropic frictionless flow. According to Hoerling et al. (1991), for global assimilated datasets with coarse vertical resolution, 3.5 PVU (1 PVU $=10^{-6} \mathrm{~m}^{2} \mathrm{~K} \mathrm{~s}^{-1} \mathrm{~kg}^{-1}$ ) represents an optimal value for the tropopause outside the Tropics. As the DAO data employed in this study have coarse vertical resolution, we chose 3.5 PVU to represent the tropopause. The dependence of the calculated monthly isentropic ozone STE on the PV tropopause definition is discussed in section $5 \mathrm{~b}$.

\section{b. Derivation of daily ozone distributions from monthly $\mathrm{PV}-\mathrm{O}_{3}$ relationships}

A major difficulty in estimating the isentropic ozone fluxes is the lack of global ozone mixing ratio distributions with spatial and temporal resolutions comparable to the advecting wind fields. It has been noted that the PV field and the ozone field are tightly correlated (e.g., Danielson 1968; Gidel and Shapiro 1980; Danielson et al. 1987; Morgenstern and Marenco 2000); this correlation is applied in this paper to derive the ozone maps.

A monthly relationship between potential vorticities and SAGE ozone mixing ratios is developed statistically on each of four isentropic surfaces (i.e., 335, 345, 355, and $365 \mathrm{~K}$ ) for each month in 1990 . There are therefore 48 scatterplots of potential vorticities and ozone mixing ratios altogether. The scatterplot on $345 \mathrm{~K}$ in January 1990 (Fig. 1) is included in this paper. It should be noted that the $y$ axis (ozone mixing ratio) uses logarithmic scaling. This is because $\mathrm{PV}$ and $\ln \left(\mathrm{O}_{3}\right)$ are found to be somewhat better correlated than $\mathrm{PV}$ and $\mathrm{O}_{3}$. Thus, we assume 


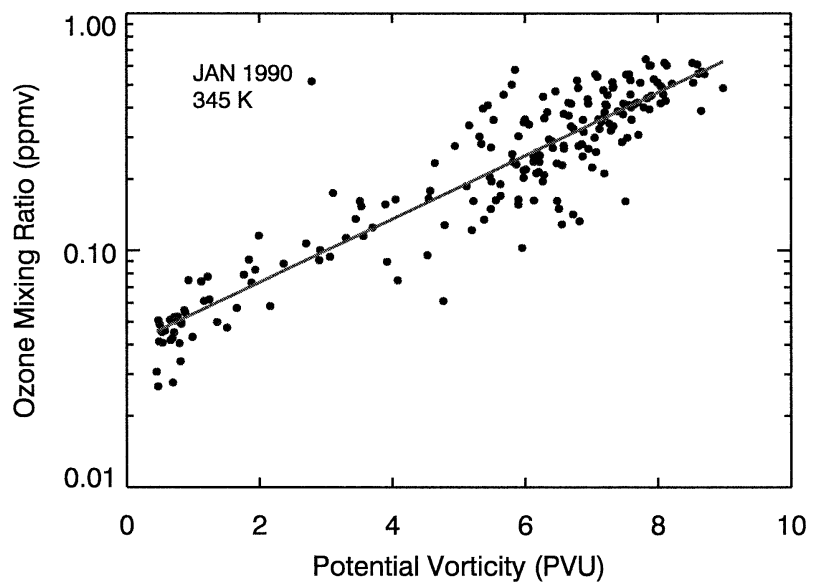

FIG. 1. Scatterplot of PV and ozone mixing ratio at $345 \mathrm{~K}$ in Jan 1990. The straight line is the linear regression line of $\mathrm{PV}$ and $\ln \left(\mathrm{O}_{3}\right)$.

$$
\ln \left(\mathrm{O}_{3}\right)=\beta_{0}+\beta_{1}(\mathrm{PV}),
$$

in which $\ln \left(\mathrm{O}_{3}\right)$ is the natural logarithm of ozone mixing ratio, $\beta_{0}$ and $\beta_{1}$ are the intersection and slope of the linear regression line of $\mathrm{PV}$ and $\ln \left(\mathrm{O}_{3}\right), \mathrm{O}_{3}$ has a unit of ppmv and PV is in PVU. The monthly slopes for the four isentropic surfaces are shown in Fig. 2 and they exhibit similar seasonal cycles. It should be noted that the large scatter in the Fig. 1 plots, which may reflect measurement uncertainties in individual SAGE ozone and PV profiles, is not producing large uncertainties in the slopes of the regression lines shown in Fig. 2. Using these 48 monthly $\mathrm{PV}-\mathrm{O}_{3}$ relationships, daily ozone mixing ratio maps are derived based on daily analyzed PV maps. The accuracy of this method is discussed in section $4 \mathrm{a}$.

\section{c. Quantification of the isentropic ozone fluxes across the tropopause}

The isentropic cross-tropopause ozone fluxes are calculated for the following isentropic surfaces in the middle world: $335,345,355$, and 365 K. Following Dethof et al. (2000a), a control volume is considered around each of the four isentropic surfaces $\theta$ (Fig. 3). Its horizontal boundary is the tropopause and its vertical boundaries are $\theta+\Delta \theta$ and $\theta-\Delta \theta(\Delta \theta=5 \mathrm{~K})$. The depth of the volume is $2 \Delta \theta(=10 \mathrm{~K})$. Therefore, the vertical bounding levels for the selected four isentropic surfaces are $330,340,350,360$, and $370 \mathrm{~K}$. The rate of change of ozone in the control volume is determined by three terms: 1) the net isentropic advection of ozone across the tropopause; 2) the vertical ozone flux due to diabatic transport; and 3) the chemical formation or destruction of ozone. Dethof et al. (2000a) used contour advection to quantify the net isentropic advection of air mass across the tropopause in the middle world. Following their approach, we developed an algorithm to estimate the net isentropic cross-tropopause ozone flux.

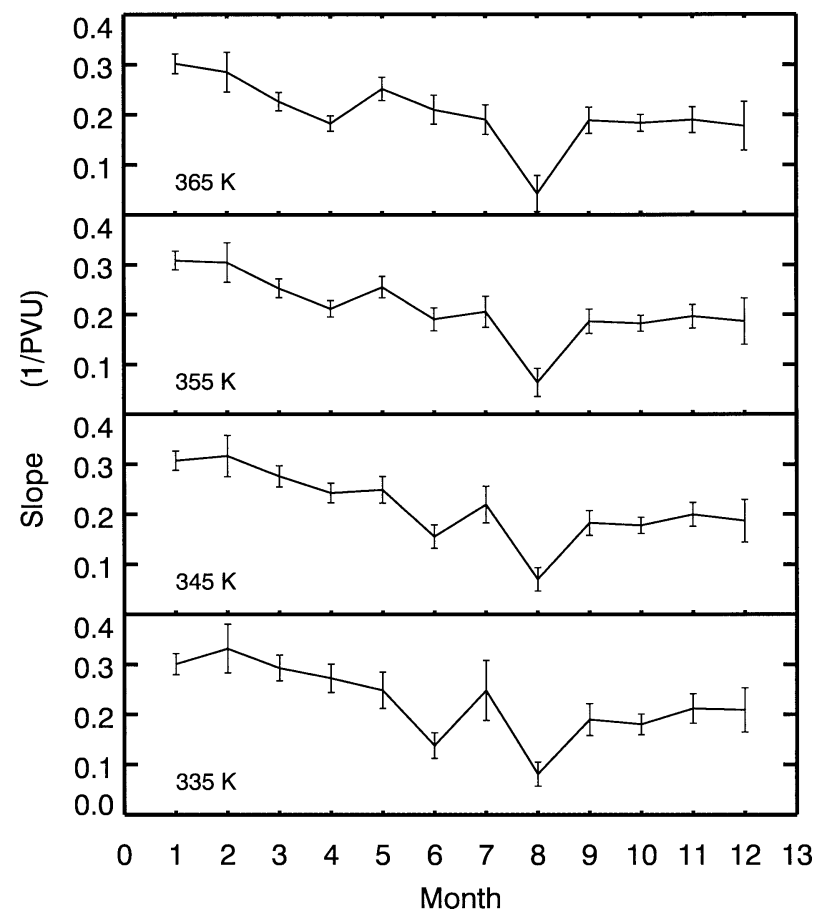

FIG. 2. Seasonal variation of slopes $\left[\Delta \ln \left(\mathrm{O}_{3}\right) / \Delta \mathrm{PV}\right]$ on four isentropic surfaces in 1990 . Error bars are two standard deviations.

The contour advection code used in this study was developed by Waugh and Plumb (1994).

On each of the four isentropic surfaces, we selected five PV contours $(1.5,2.5,3.5,4.5$, and 5.5 PVU) for the contour advection calculation. The initial locations (determined by the longitude and latitude) of these five contours on each isentropic surface are generated from DAO analysis on day 0 , by choosing the longest continuous contours (i.e., neglecting the smaller blobs; Fig. 4a). The 3.5-PVU contour on day 0 is identified as the initial dynamical tropopause, which acts as a quasi-horizontal boundary of the initial control volume.

Next, the five initial DAO PV contours were run using contour advection for 5 days. The wind field was renewed every $6 \mathrm{~h}$. The duration of a 5-day calculation

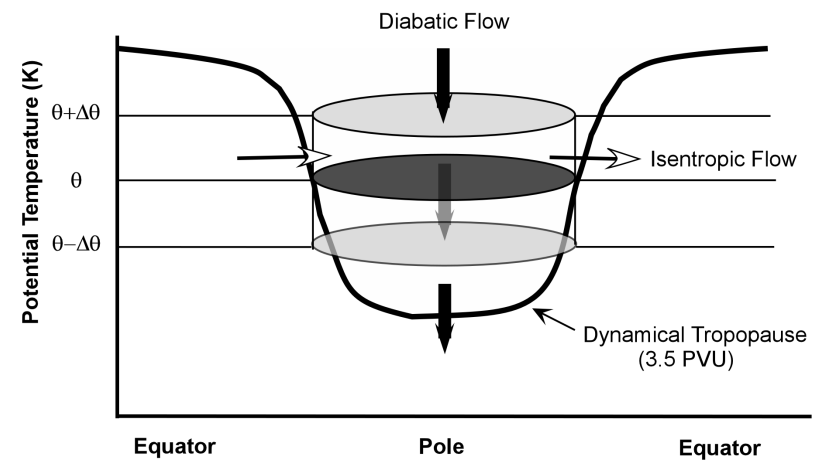

FIG. 3. A schematic illustration of a control volume around the surface $\theta$ (adapted from Dethof et al. 2000a). 
(a)

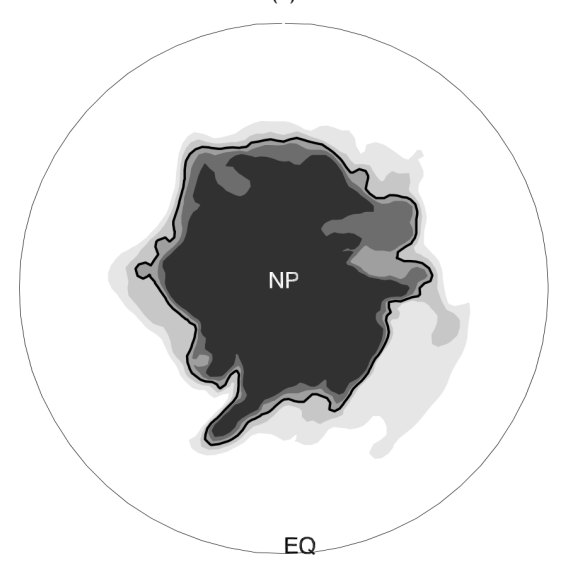

(b)

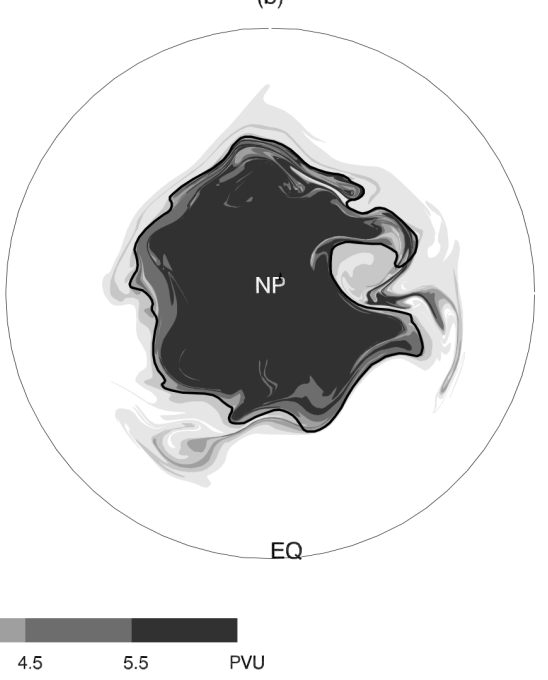

FIG. 4. An example of the algorithm results for calculating the isentropic ozone flux across the dynamical tropopause at $345 \mathrm{~K}$. (a) Initial PV field from DAO analyses on $1 \mathrm{Feb} 1990$ after neglecting smaller blobs of PV contours. The thick black contour represents the initial tropopause defined by 3.5 PVU. (b) Final PV field on 6 Feb 1990 after 5-day contour advection calculation. The thick black contour is the final tropopause determined by running the surgery routine of contour advection on the 3.5-PVU contour. In (a) and (b) NP represents the North Pole and the outside circle is the equator. The $\mathrm{S} \rightarrow \mathrm{T}$ transport is represented by those structures equatorward of the final tropopause with PV values $>3.5 \mathrm{PVU}$. The $\mathrm{T} \rightarrow \mathrm{S}$ transport is associated with those structures poleward of the final tropopause with PV values $<3.5$ PVU.

is long enough for the full development of the filaments (Dethof et al. 2000a) and is short enough for the PV to be considered as a quasi-conservative tracer (Andrews et al. 1987). Because the chemical lifetime of ozone in the LS and UT is about 100 days (Wang et al. 1998b), ozone can also be considered as conserved over the 5day period.

On the fifth day of each calculation on each isentropic surface, the final PV field distribution is represented by the position of the five PV contours following the contour advection. This PV field is characterized by the presence of filaments (Fig. 4b). To determine the new position of the dynamical tropopause, a separate 5-day run of the contour advection calculation is done only on the 3.5-PVU contour but this time running with surgery. The surgery routine removes those filaments on the 3.5-PVU contour by merging or disconnecting two structures within a specified cutoff scale $\delta$ every $24 \mathrm{~h}$. The cutoff scale increases $0.008 R$ ( $R$ is the radius of the earth) every $24 \mathrm{~h}$. The final cutoff scale is $0.04 R$ $(\sim 250 \mathrm{~km})$, which is close to the grid resolution of the initial DAO PV field. Structures below this scale are assumed to have been dissipated and irreversibly transported into the troposphere or stratosphere. In the end, the final dynamical tropopause is represented by the coarse-scale 3.5-PVU contour on day 5 produced by the contour advection with surgery (Fig. 4b).

"Overlapping" this coarse final tropopause onto the PV field from the contour advection calculations on day 5 (Fig. 4b) yields small-scale structures in this PV field poleward and equatorward of the tropopause. For the equatorward structures, if the PV values within them are greater than 3.5 PVU, we infer that they represent stratosphere-to-troposphere $(\mathrm{S} \rightarrow \mathrm{T})$ transport. On the other hand, for the poleward structures, if their PV values are smaller than 3.5 PVU, we assume that they represent troposphere-to-stratosphere $(\mathrm{T} \rightarrow \mathrm{S})$ transport. Gridding those finescale structures onto a regular $0.25^{\circ}$ $\times 0.25^{\circ}$ (latitude by longitude) grid, we can calculate the mass of the ozone $(M)$ being transported either from $\mathrm{S} \rightarrow \mathrm{T}$ or from $\mathrm{T} \rightarrow \mathrm{S}$ globally by summing over the grid boxes

$$
\begin{array}{ll}
M_{\mathrm{S} \rightarrow \mathrm{T}}=\sum_{i} \sigma_{i} r_{i} \beta_{i} \Delta x \Delta y 2 \Delta \theta & \text { if } \beta_{i}=-1 \\
M_{\mathrm{T} \rightarrow \mathrm{S}}=\sum_{i} \sigma_{i} r_{i} \beta_{i} \Delta x \Delta y 2 \Delta \theta & \text { if } \beta_{i}=+1,
\end{array}
$$

in which $\sigma_{i}$ is the isentropic density of the air in grid box $i ; r_{i}$ is the isentropic ozone mixing ratio by mass obtained from the $\mathrm{PV}-\mathrm{O}_{3}$ monthly relationships; $\beta_{i}$ is set to be -1 if $\mathrm{PV}$ in grid box $i$ is $>3.5 \mathrm{PVU}$ and +1 if PV $<3.5$ PVU; $\Delta x$ and $\Delta y$ are the grid sizes; and $2 \Delta \theta(=10 \mathrm{~K})$ is the isentropic depth of the grid boxes. The daily isentropic flux of ozone, either from $\mathrm{S} \rightarrow \mathrm{T}$ or from $\mathrm{T} \rightarrow \mathrm{S}$, is obtained by dividing $M$ by the calculation time (5 days). Adding the fluxes in the two directions, we get the net isentropic ozone flux. New calculations are started every day. To yield the monthly and annual fluxes, the daily fluxes are summed over time. Sensitivity analysis, which is described in section 
TABLE 1. Medians and standard deviations of the differences [("PV mapped"-sonde)/sonde] between ozone mixing ratios from $\mathrm{PV}-\mathrm{O}_{3}$ relationships and from ozonesonde observations at Hohenpeissenberg, Germany, in 1990.

\begin{tabular}{|c|c|c|}
\hline \multirow{2}{*}{$\begin{array}{c}\text { Potential } \\
\text { temperature }(\mathrm{K})\end{array}$} & \multicolumn{2}{|c|}{$\begin{array}{l}\text { Hohenpeissenberg }\left(47.5^{\circ} \mathrm{N}, 11.0^{\circ} \mathrm{E}\right) \\
120 \text { collected profiles }\end{array}$} \\
\hline & Medians (\%) & Standard deviations (\%) \\
\hline $365 \mathrm{~K}$ & 5.9 & 31.8 \\
\hline $355 \mathrm{~K}$ & 6.2 & 27.4 \\
\hline $345 \mathrm{~K}$ & -4.2 & 27.3 \\
\hline $335 \mathrm{~K}$ & -14.7 & 26.3 \\
\hline
\end{tabular}

5c, shows that approximately $90 \%$ of the isentropic ozone transport across this dynamically defined tropopause (i.e., 3.5 PVU) is associated with PV values between 1.5 and 5.5 PVU.

\section{Results}

\section{a. PV-mapped ozone}

The accuracy of the relationship between SAGE II ozone and PV on each isentropic surface has been assessed by comparing the inferred ozone values against ozone mixing ratios from ozonesonde observations at Hohenpeissenberg, Germany $\left(47.5^{\circ} \mathrm{N}, 11.0^{\circ} \mathrm{E}\right)$, in 1990 . To make the comparisons coincident, the PV-mapped ozone mixing ratios are linearly interpolated both in space and in time to match the locations and times of the observations. The ozonesonde data are vertically interpolated onto the four isentropic surfaces using the interpolation method in Edouard et al. (1997).

The differences between PV-mapped ozone mixing ratios and the ozonesonde measurements are listed in Table 1 . The median agreement is within $10 \%$ except on the $335-\mathrm{K}$ surface $(-14.7 \%)$. This indicates that PVmapped ozone mixing ratios are underestimated on 335 K. Figure 5 shows the comparison between the time series of PV-mapped and ozonesonde-measured ozone mixing ratios on $345 \mathrm{~K}$. It demonstrates that the PVmapped ozone mixing ratios are highly correlated with ozonesonde measurements. The correlation coefficients on all four isentropic surfaces over Hohenpeissenberg are greater than 0.85 . It is also evident that the mappings have captured the magnitudes and the seasonal variations in ozone mixing ratio at midlatitudes (i.e., Hohenpeissenberg). In the Tropics, for example, at Hilo, Hawaii $\left(19.7^{\circ} \mathrm{N}, 155.6^{\circ} \mathrm{W}\right)$, the median agreement between PV-mapped ozone mixing ratios and ozonesonde measurements (not shown) is still around $10 \%$, but a smaller correlation coefficient $(\sim 0.60)$ and a bigger standard deviation $(\sim 50 \%)$ of the differences are exhibited. Fortunately, the uncertainties in the Tropics are of little concern in this study, as the isentropic crosstropopause transport mostly occurs at midlatitudes (addressed in section $4 \mathrm{~d}$ ).

The median PV-mapped/sonde ozone differences shown in Table 1 contain contributions from a range of

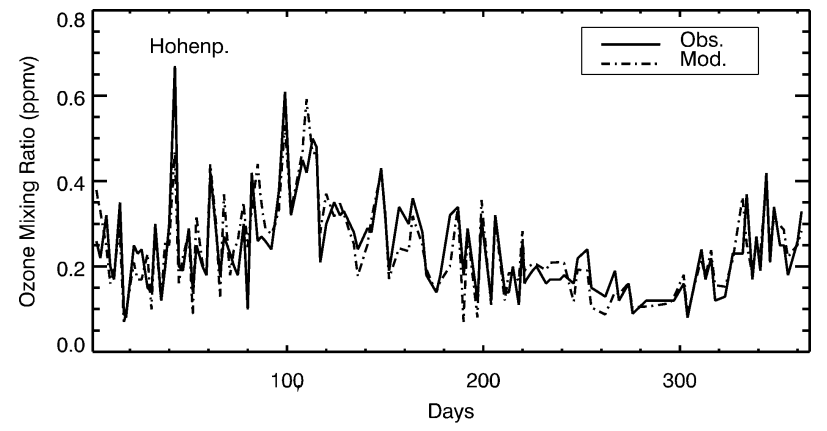

FIG. 5. Ozone from sonde observations vs ozone from monthly $\mathrm{PV}-\mathrm{O}_{3}$ relationships at $345 \mathrm{~K}$ over Hohenpeissenberg, Germany, in 1990.

PV values on each isentropic surface. Since SAGE ozone is known to be biased low in the troposphere, with the bias reaching $-30 \%$ approximately $2 \mathrm{~km}$ below the tropopause (Wang et al. 2002), we need to see whether this will bias the ozone flux results. For just the tropospheric PV-mapped/sonde comparisons on $335 \mathrm{~K}$, $\mathrm{PV}$-mapped tropospheric ozone values are calculated to be $3 \%$ larger than the ozonesonde values at Hohenpeissenberg. This unexpected result occurs because of the overestimation of the low SAGE tropospheric ozone values by the linear regression based on the PV mapping procedure (see where PV $<1$ PVU in Fig. 1). The difference between the PV-mapped ozone in both the troposphere and the stratosphere and the sondes are therefore sufficiently small $(\leq 10 \%)$ that no corrections for possible ozone measurements biases have been made to the calculated ozone fluxes.

\section{b. Estimated monthly isentropic cross-tropopause ozone fluxes}

Figure 6 shows the estimated monthly isentropic cross-tropopause ozone fluxes at 335, 345, 355, and 365 $\mathrm{K}$. According to the plot of the net fluxes, the $\mathrm{S} \rightarrow \mathrm{T}$ fluxes are greater than the $\mathrm{T} \rightarrow \mathrm{S}$ fluxes in magnitude in every month at all four isentropic levels except for April on 355 and $365 \mathrm{~K}$. This means the net ozone fluxes are almost always directed from the extratropical LS to the subtropical UT. It is shown that both the $\mathrm{S} \rightarrow \mathrm{T}$ and $\mathrm{T} \rightarrow \mathrm{S}$ fluxes are stronger in summer/fall than in winter/ spring. This agrees with the mixing properties of the isentropic flow in the middle world. The isentropic mixing in the LS and UT is strongest in summer and weakest in winter because the extratropical tropopause barriers are strongest in winter and are considerably weakened by the monsoon circulations in summer (Haynes and Shuckburgh 2000). For the four layers combined, the maximum net $\mathrm{S} \rightarrow \mathrm{T}$ ozone flux occurs in August and the minimum occurs in April (not shown). This is opposite to the seasonality of the downward diabatic ozone flux between $30^{\circ}$ and $60^{\circ} \mathrm{N}$, which has a maximum in April and a minimum in September (Olsen et al. 2002). 


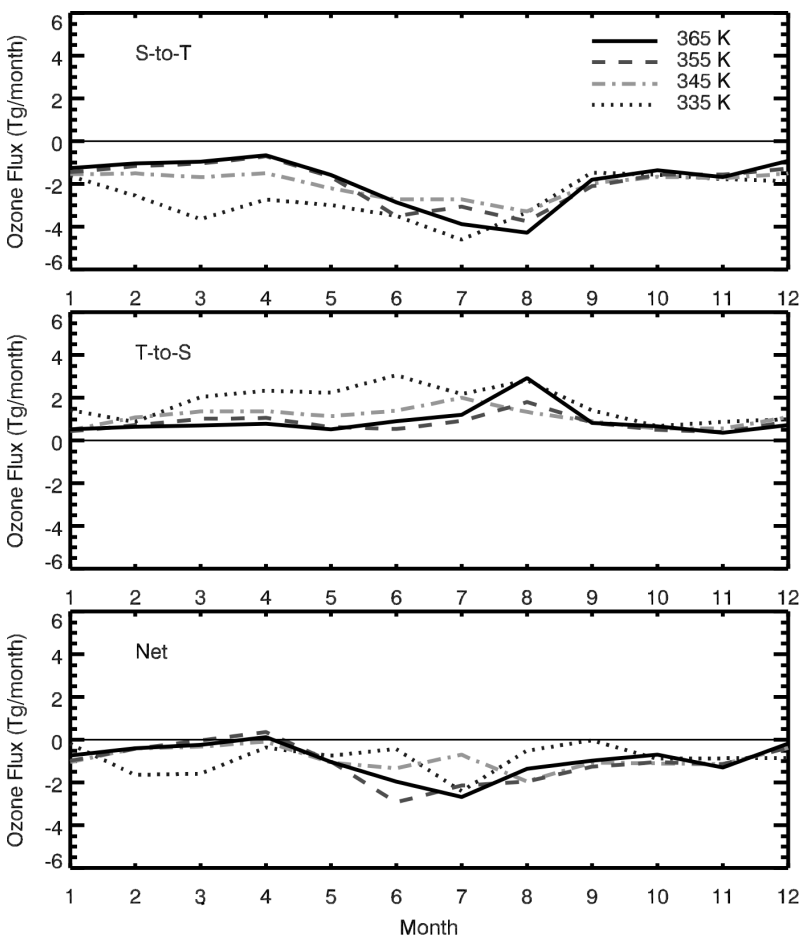

FIG. 6. Estimated monthly isentropic ozone fluxes across the tropopause for four isentropic layers in 1990. Negative values are from the stratosphere to the troposphere and positive values are from the troposphere to the stratosphere.

Wang et al. (1998a) showed that from spring to summer, the SAGE II measurements in the NH display a rapid decrease in the ozone columns poleward of $30^{\circ} \mathrm{N}$, accompanied by an increase in the ozone columns at low latitudes in the layer between 330 and $380 \mathrm{~K}$, and the extratropical ozone continues to decrease in the fall. In winter, the ozone-rich air is transported from higher altitudes into the extratropical LS by the strong largescale diabatic circulation (Holton et al. 1995), and it will be stored there because the photochemistry is weak and the extratropical tropopause barrier is strong. This ozone-rich air will spread into the subtropical UT via isentropic transport in summer because the PV gradients are the smallest in summer and they thus act as weaker barriers to the cross-tropopause transport (Chen 1995; Haynes and Shuckburgh 2000). However, as the photochemistry of ozone is also more active in summer, it is hard to infer a direct connection between the ozone changes in the UT and the isentropic transport.

It may be noted from Fig. 6 that the seasonality of the ozone fluxes is more obvious on isentropic surfaces above $340 \mathrm{~K}$ (i.e., 345, 355, and $365 \mathrm{~K}$ ) than on 335 $\mathrm{K}$. For $335 \mathrm{~K}$, there is a secondary maximum of net ozone flux around February/March. This is because the barrier posed by the horizontal PV gradients in winter is not as strong on lower surfaces as it is on the upper ones and therefore the cross-tropopause transport can occur all year-round at lower levels. This is consistent with the characteristics of the two mass transport regimes in the middle world found by Chen (1995) and Dethof et al. (2000a).

\section{c. Annual isentropic cross-tropopause ozone fluxes}

The estimated $\mathrm{S} \rightarrow \mathrm{T}$ annual ozone flux for all the four levels (i.e., in the layer between 330 and $370 \mathrm{~K}$ ) is $100 \mathrm{Tg} \mathrm{yr}^{-1}\left(1 \mathrm{Tg}=10^{9} \mathrm{~kg}\right)$. It is approximately twice the $\mathrm{T} \rightarrow \mathrm{S}$ flux (54 $\mathrm{Tg} \mathrm{yr}^{-1}$ ) in magnitude. There-

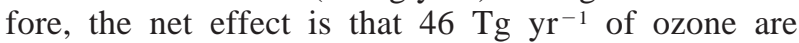
isentropically transported from the extratropical LS into the subtropical UT in the NH.

We are unaware of any other studies that have provided estimates of the isentropic cross-tropopause ozone transport. However, Olsen et al. (2003) estimated the downward ozone flux including diabatic effects across the tropopause at midlatitudes in the $\mathrm{NH}$, but they did not consider the upward flux. Their annual downward $\mathrm{S} \rightarrow \mathrm{T}$ ozone flux is $\sim 260 \mathrm{Tg} \mathrm{yr}^{-1}$ in the $\mathrm{NH}$, which is twice the isentropic $\mathrm{S} \rightarrow \mathrm{T}$ flux $\left(100 \mathrm{Tg} \mathrm{yr}^{-1}\right)$ in this study. This emphasizes that, from a global perspective, large-scale diabatic transport processes make important contributions to the ozone STE.

Shepherd et al. (2000) have suggested that the ability of contour advection to reproduce small-scale structures from low-resolution wind fields may be restricted to regions such as the winter stratospheric polar vortex or the upper stratosphere, where the dynamics are known to be dominated by large-scale processes. Near the tropopause there is more energy at smaller scales and the dynamics are more controlled by local processes. It is possible therefore that the contour advection technique does not capture all the small scales evolving around the tropopause using the coarse-resolution $(\sim 250 \mathrm{~km})$ wind fields from the GEOS-1 assimilation model and of the observed fields on which these wind fields are based. Higher-resolution winds might yield larger estimates of the isentropic fluxes at the tropopause. The possibility that the air near the tropopause could undergo "fake" cross-tropopause transport when the transported air had a very short residence time has not been investigated.

\section{d. Relationship of the isentropic ozone fluxes to wave activities}

Figure 7 shows the geographical distributions of the estimated monthly isentropic ozone fluxes from $\mathrm{S} \rightarrow \mathrm{T}$ and from $\mathrm{T} \rightarrow \mathrm{S}$ at 345 and $355 \mathrm{~K}$ for February and August. The $\mathrm{S} \rightarrow \mathrm{T}$ fluxes are larger than the $\mathrm{T} \rightarrow \mathrm{S}$ fluxes. Therefore, the distributions of the net fluxes (which are not shown in this paper) are very similar to those of the $S \rightarrow T$ fluxes. In February, the $S \rightarrow T$ ozone fluxes occur predominantly in the midlatitude regions of the eastern Atlantic Ocean and northwest Africa both at 345 and $355 \mathrm{~K}$. There is a secondary ozone flux maximum over the eastern Pacific Ocean at $345 \mathrm{~K}$. 


\section{S-to-T}

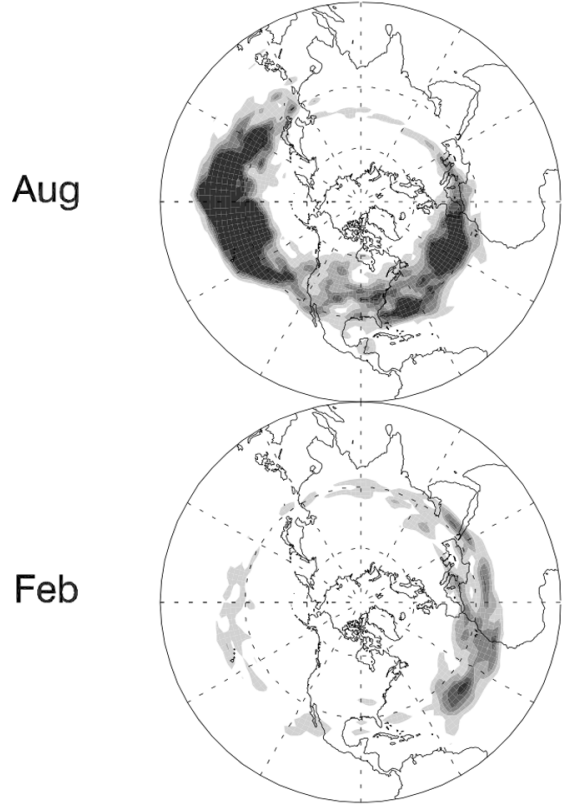

\section{S-to-T}

.

Aug

Feb

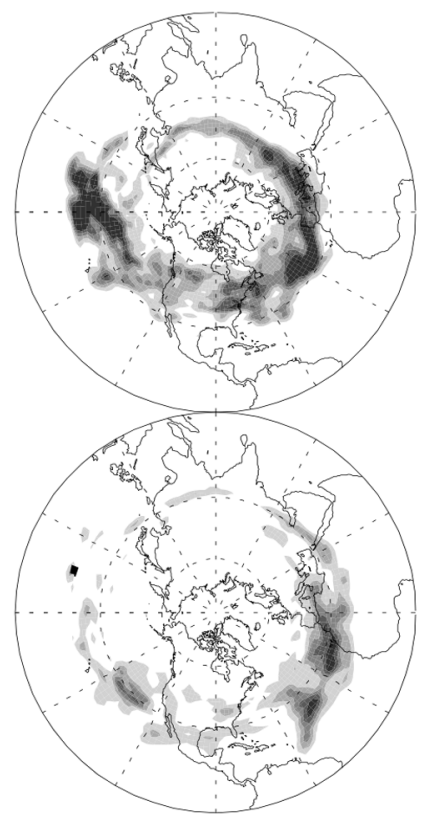

$355 \mathrm{~K}$

$355 \mathrm{~K}$

$345 \mathrm{~K}$

$345 \mathrm{~K}$
Aug

Feb

\section{T-to-S}

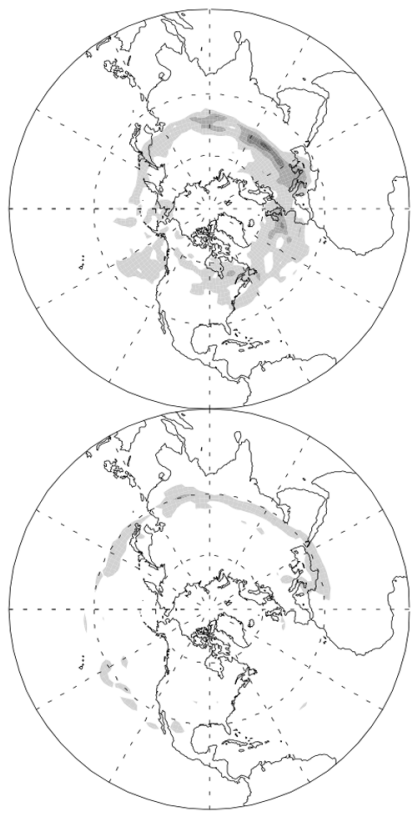

T-to-S

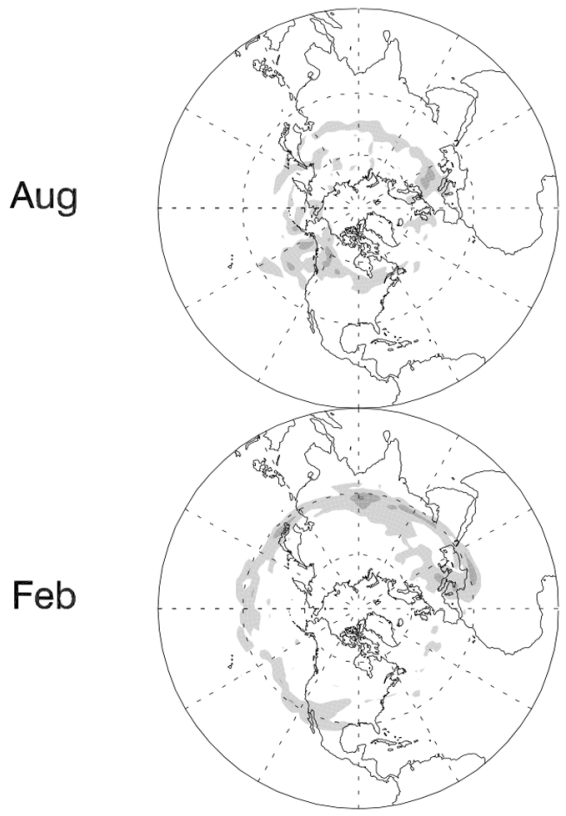

$355 \mathrm{~K}$

$355 \mathrm{~K}$

$345 \mathrm{~K}$

\section{4 \\ 0.8 \\ 1.2 \\ 1.6 \\ 2.0 \\ $10^{\wedge} 6 \mathrm{~kg} / \mathrm{mon}$}

FIG. 7. Distributions of the magnitudes of the estimated monthly isentropic ozone fluxes from $S \rightarrow T$ and from $T \rightarrow S$ in Feb and Aug 1990. The upper four plots are for the isentropic surface of $355 \mathrm{~K}$ and the lower four are for $345 \mathrm{~K}$. 
TABLE 2. Estimated monthly isentropic cross-tropopause ozone fluxes (in $10^{9} \mathrm{~kg} \mathrm{month}{ }^{-1}$ ) between 330 and $370 \mathrm{~K}$ in Feb and Aug 1990 for different cutoff-scale values. The shaded values are for the $250-\mathrm{km}$ cutoff scale chosen in this study. The tropopause is defined by 3.5 PVU.

\begin{tabular}{|c|c|c|c|c|c|c|c|c|c|}
\hline & \multicolumn{3}{|c|}{$\mathrm{S} \rightarrow \mathrm{T}$} & \multicolumn{3}{|c|}{$\mathrm{T} \rightarrow \mathrm{S}$} & \multicolumn{3}{|c|}{$\mathrm{Net}$} \\
\hline & $190 \mathrm{~km}$ & $250 \mathrm{~km}$ & $320 \mathrm{~km}$ & $190 \mathrm{~km}$ & $250 \mathrm{~km}$ & $320 \mathrm{~km}$ & $190 \mathrm{~km}$ & $250 \mathrm{~km}$ & $320 \mathrm{~km}$ \\
\hline Feb & -5.55 & -6.20 & -6.56 & 3.24 & 3.36 & 3.55 & -2.31 & -2.84 & -3.01 \\
\hline Aug & -14.25 & -14.60 & -15.38 & 8.65 & 8.90 & 9.01 & -5.60 & -5.70 & -6.37 \\
\hline
\end{tabular}

These results are consistent with the distribution of the wave breaking intensity in winter proposed by Scott and Cammas (2002). In August, the $\mathrm{S} \rightarrow \mathrm{T}$ ozone fluxes are located primarily over the Pacific and Atlantic Oceans, where Rossby wave breaking preferentially occurs around $350 \mathrm{~K}$ in summer (Postel and Hitchman 1999; Scott and Cammas 2002). Although they are smaller in magnitude, the $\mathrm{T} \rightarrow \mathrm{S}$ fluxes are shown to occur more frequently over midlatitude Europe and Asia both in February and in August and over North America in August. This indicates that wave breaking is also associated with $\mathrm{T} \rightarrow \mathrm{S}$ transport.

\section{Sensitivity analysis}

\section{a. Cutoff scale in contour advection}

The surgery routine in contour advection removes the filaments below a prescribed cutoff scale $\delta$. Dethof et al. (2000a,b) used a final cutoff scale of $0.05 R(\sim 320$ $\mathrm{km})$, which was close to the grid size of the analyzed PV field they employed. In this work, the cutoff scale is set to be $0.04 R(\sim 250 \mathrm{~km})$ because this is the resolution of DAO analyzed data. To test how sensitive the estimated ozone fluxes are to the cutoff-scale values, we ran the model in February and August with three different $\delta$ values: $0.03 R(\sim 190 \mathrm{~km}), 0.04 R(\sim 250 \mathrm{~km})$, and $0.05 R(\sim 320 \mathrm{~km})$. The test results are listed in Table 2 . They show that the differences in the monthly ozone fluxes (both $\mathrm{S} \rightarrow \mathrm{T}$ and $\mathrm{T} \rightarrow \mathrm{S}$ ) in February and August are less than $10 \%$.

It was indicated earlier that small blobs in the analyzed PV maps have been neglected in the initialization of the contour advection calculations. These small blobs typically coincide with filaments of PV from earlierinitiated contour advection calculations. Therefore the contribution of the blobs to the fluxes will have been included in the calculations made a few days earlier.

\section{b. PV value used to define the tropopause}

The flux calculations have been compared using three different PV values to define the tropopause: $2.5,3.5$, and 4.5 PVU. It is shown in Table 3 that the magnitudes of the estimated ozone fluxes (both $\mathrm{S} \rightarrow \mathrm{T}$ and $\mathrm{T} \rightarrow \mathrm{S}$ ) decrease with increasing tropopause PV values in August. This is mainly because the areas of the filaments that are identified as $\mathrm{S} \rightarrow \mathrm{T}$ or $\mathrm{T} \rightarrow \mathrm{S}$ transport decrease as higher PV values are chosen to represent the tropopause (Scott and Cammas 2002). In February, however, the fluxes increase with increasing tropopause PV values. This is in part because ozone mixing ratio increases more dramatically with PV in winter than in summer (Fig. 2). It is also noted that the changes in $\mathrm{S} \rightarrow \mathrm{T}$ fluxes are more pronounced than those of the $\mathrm{T} \rightarrow \mathrm{S}$ fluxes. This is because the ozone mixing ratio increases exponentially with PV [Eq. (1)]. Therefore, the ozone fluxes increase faster with increasing PV at higher PV values $(\mathrm{S} \rightarrow \mathrm{T})$ than at lower PV values $(\mathrm{T} \rightarrow \mathrm{S})$.

\section{c. Cross-tropopause ozone transport outside the 1.5- 5.5-PVU range}

Table 4 shows how much of the ozone exchange across the 3.5-PVU tropopause occurs outside the range of 1.5-5.5 PVU (i.e., $0<\mathrm{PV}<1.5 \mathrm{PVU}$ or $\mathrm{PV}>5.5$ PVU) in February and August 1990. The ozone flux within the range of $0<\mathrm{PV}<1.5 \mathrm{PVU}$ (or $\mathrm{PV}>5.5$ PVU) is estimated by calculating the amount of ozone enclosed between the 1.5-PVU (or 5.5 PVU) contour and the tropopause contour. The amount of ozone transferred into the stratosphere from PV values less than 1.5 PVU is less than $5 \%$ of the estimated total $\mathrm{T} \rightarrow \mathrm{S}$ ozone flux. For PV values greater than 5.5 PVU, it is $\sim 10 \%$ of the estimated total $\mathrm{S} \rightarrow \mathrm{T}$ ozone flux. This demonstrates that the isentropic ozone STE mostly occurs between 1.5 and 5.5 PVU in the middle world. This

TABLE 3. Similar to Table 2 for a cutoff scale of $250 \mathrm{~km}$, but for different PV values chosen to define the tropopause. The shaded values are for the PV value used in this study.

\begin{tabular}{|c|c|c|c|c|c|c|c|c|c|}
\hline & \multicolumn{3}{|c|}{$\mathrm{S} \rightarrow \mathrm{T}$} & \multicolumn{3}{|c|}{$\mathrm{T} \rightarrow \mathrm{S}$} & \multicolumn{3}{|c|}{ Net } \\
\hline & $2.5 \mathrm{PVU}$ & $3.5 \mathrm{PVU}$ & $4.5 \mathrm{PVU}$ & $2.5 \mathrm{PVU}$ & $3.5 \mathrm{PVU}$ & $4.5 \mathrm{PVU}$ & $2.5 \mathrm{PVU}$ & $3.5 \mathrm{PVU}$ & $4.5 \mathrm{PVU}$ \\
\hline Feb & -4.13 & -6.20 & -8.01 & 2.87 & 3.36 & 4.04 & -1.26 & -2.84 & -3.97 \\
\hline Aug & -18.20 & -14.60 & -12.25 & 8.40 & 8.90 & 7.97 & -9.80 & -5.70 & -4.28 \\
\hline
\end{tabular}


TABLE 4. Estimated monthly isentropic ozone fluxes (in $10^{9} \mathrm{~kg}$ month ${ }^{-1}$ ) across the 3.5-PVU tropopause between 330 and $370 \mathrm{~K}$ in Feb and Aug for PV values less than 1.5 PVU (from $\mathrm{T} \rightarrow \mathrm{S}$ ) and greater than 5.5 PVU (from $\mathrm{S} \rightarrow \mathrm{T}$ ). The percentages in the column of $<1.5$ PVU are calculated by comparing to the monthly $\mathrm{T} \rightarrow \mathrm{S}$ fluxes for PV $<3.5$ PVU. The percentages in the column of $>5.5$ $\mathrm{PVU}$ are with respect to the monthly $\mathrm{S} \rightarrow \mathrm{T}$ fluxes for $\mathrm{PV}>3.5$ PVU.

\begin{tabular}{llc}
\hline \hline & $<1.5$ PVU & $>5.5$ PVU \\
\hline Feb & $0.09(\sim 3 \%)$ & $-0.81(\sim 13 \%)$ \\
Aug & $0.46(\sim 5 \%)$ & $-1.66(\sim 11 \%)$ \\
\hline
\end{tabular}

is consistent with the results of Dethof et al. (2000a), who showed that $80 \%$ of the $\mathrm{S} \rightarrow \mathrm{T}$ (or $\mathrm{T} \rightarrow \mathrm{S}$ ) isentropic airmass transport occurs within $15^{\circ}$ (or $10^{\circ}$ ) equivalent latitude from the 3.5-PVU tropopause contour; the distance between 1.5 and 5.5 PVU is approximately $20^{\circ}$ in equivalent latitude.

\section{Summary and discussion}

The objective of this investigation was to estimate how much ozone is transported across the tropopause through isentropic processes. These processes are acknowledged to be an effective mechanism of stratosphere-troposphere exchange (Holton et al. 1995; Chen 1995; Dethof et al. 2000a,b). Using SAGE II ozone measurements and potential vorticities from the DAO model, daily ozone maps were derived based on monthly $\mathrm{PV}-\mathrm{O}_{3}$ relationships and daily analyzed PV maps. The procedure for deriving ozone maps from monthly PV$\mathrm{O}_{3}$ relationships has been shown to be an effective way to obtain global ozone distributions in the midlatitude lower stratosphere and upper troposphere. Comparing the PV-mapped ozone with ozonesondes at Hohenpeissenberg $\left(47.5^{\circ} \mathrm{N}, 11.0^{\circ} \mathrm{E}\right)$, the agreement in the mean is approximately 10\% [("PV mapped"-sonde)/sonde].

The net isentropic ozone fluxes across the tropopause have been estimated in the Northern Hemisphere for the year 1990 using contour advection. Although the monthly isentropic ozone fluxes from stratosphere to troposphere and from troposphere to stratosphere are of the same order of magnitude, the net effect is that ozone is transported from the extratropical lower stratosphere (LS) into the subtropical upper troposphere (UT). As the calculated monthly ozone fluxes are the strongest in summer, the isentropic stratosphere-troposphere exchange tends to produce a decrease of ozone in the LS and an increase of ozone in the UT in summertime. Such ozone changes in the LS and UT have been observed by SAGE II measurements (Wang et al. 1998a). However, further modeling studies need to be performed in order to draw a more definitive conclusion regarding the relationship between the observed ozone tendencies and isentropic ozone transport, because our study did not consider chemically induced ozone changes or diabatic processes.

Our estimated annual isentropic stratosphere-to-tro- posphere ozone flux between 330 and $370 \mathrm{~K}$ in the

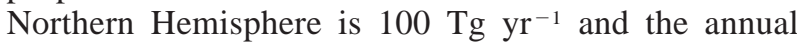
troposphere-to-stratosphere ozone flux is $54 \mathrm{Tg}^{-1}$. The net amount of ozone that is transported into the subtropical upper troposphere annually is $46 \mathrm{Tg}^{-1}$. The possible sources of error in our estimates of isentropic ozone STE have been indicated. A possible bias of $\pm 10 \%$ for PV-mapped ozone in the lowermost stratosphere and upper troposphere results in an uncertainty of $\pm 10 \mathrm{Tg} \mathrm{yr}^{-1}\left( \pm 5 \mathrm{Tg} \mathrm{yr}^{-1}\right)$ in the estimated $\mathrm{S} \rightarrow \mathrm{T}$ $(\mathrm{T} \rightarrow \mathrm{S})$ fluxes. The uncertainty induced by a change of approximately $\pm 60 \mathrm{~km}$ in the cutoff scale used for the contour advection calculations produces $\pm 6{\mathrm{Tg} \mathrm{yr}^{-1}}^{-1}$ $\left( \pm 2 \mathrm{Tg} \mathrm{yr}^{-1}\right)$ in the estimates and the largest uncertainty is caused by \pm 1 PVU in the tropopause definition, which results in $\pm 25 \mathrm{Tg} \mathrm{yr}^{-1}\left( \pm 6 \mathrm{Tg} \mathrm{yr}^{-1}\right)$ in the estimated $\mathrm{S} \rightarrow \mathrm{T}(\mathrm{T} \rightarrow \mathrm{S})$ fluxes. The root-sum-square uncertainties are thus $\pm 28 \%( \pm 15 \%)$ in the $\mathrm{S} \rightarrow \mathrm{T}$ $(\mathrm{T} \rightarrow \mathrm{S}$ ) fluxes and the net isentropic $\mathrm{S} \rightarrow \mathrm{T}$ ozone flux is $46 \pm 29 \mathrm{Tg} \mathrm{yr}^{-1}$.

These estimated isentropic ozone fluxes are significantly smaller than the downward stratosphere-to-troposphere ozone flux including diabatic effects estimate of $260 \mathrm{Tg} \mathrm{yr}^{-1}$ by Olsen et al. (2003), but they did not estimate the troposphere-to-stratosphere ozone flux. There is other evidence that diabatic processes may, in fact, dominate the exchange (Schoeberl 2003, personal communication). It should also be noted that the calculations in our study could have underestimated the isentropic ozone fluxes due to the restricted ability of contour advection to reproduce the small scales at the tropopause from coarse-resolution wind fields (Shepherd et al. 2000).

From a global viewpoint, the isentropic cross-tropopause exchange of ozone may be a smaller contributor to the total ozone budget in the troposphere than diabatic exchange. However, the two STE processes play different roles in affecting the ozone budget in the UT. The diabatic processes transfer stratospheric ozone downward into the UT mainly in the extratropics (Holton et al. 1995) and they tend to increase the latitudinal gradient of ozone concentrations between the extratropical LS and tropical UT. On the other hand, isentropic transport tends to decrease this gradient by spreading the ozone-rich air that is stored in the extratropics into the Tropics quasi horizontally across the subtropical tropopause. Therefore, isentropic transport could be an important controlling factor for ozone variations in the tropical/subtropical UT under certain circumstances. For example, laminae with high ozone mixing ratios (up to 120 ppbv) have often been observed in the upper troposphere over the tropical Indian Ocean during February-March 1998 (Zachariasse et al. 2000). Back-trajectory analysis indicated that these ozone-rich laminae had a stratospheric origin and that they were transported quasi horizontally toward the equator by filamentations around the subtropical jet stream. In another study, Morgenstern and Carver (2001) showed that anomalies of 
ozone mixing ratios derived from the Measurement of Ozone and Water Vapor by Airbus In-Service Aircraft (MOZAIC) observations for five winters in 1995 to 1999 occurred most frequently in a belt spanning the subtropical North Atlantic and the Mediterranean. According to their model studies, isentropic transport of filamentary structures occurred in this region. However, neither of these papers quantitatively analyzed how much ozone was being transported by these filaments.

Qualitatively, it is safe to say that isentropic ozone transfer across the tropopause is important for sporadic short-term ozone variations in the subtropical upper troposphere. However, it is difficult at present to corroborate the quantitative contribution of isentropic processes to the ozone budget in the subtropical/tropical UT, due to the lack of ozone observations with global coverage and fine resolution in the upper troposphere. Recent modeling studies (Lamarque et al. 1999; Emmons et al. 2003) have addressed the influence of STE on tropospheric chemistry. However, their modeling regime was located below the $300-\mathrm{hPa}$ isobaric surface $(\sim 310 \mathrm{~K})$, where the tropopause seldom intersects isentropic surfaces and cross-tropopause transport mostly occurs diabatically (Hoskins 1991; Holton et al. 1995).

Studies have acknowledged that isentropic transport is associated with wave breaking events (i.e., Norton 1994; Holton et al. 1995; Postel and Hitchman 1999). In this paper the isentropic cross-tropopause ozone transport is found predominantly over the eastern Atlantic Ocean and northwest Africa in winter and over the Atlantic and Pacific Oceans in summer, where wave breaking preferentially occurs (Postel and Hichman 1999; Scott and Cammas 2002). The challenge remains to seek observational evaluations of the estimates of isentropic cross-tropopause ozone transport. It is also important that statistical analysis be carried out on the relationship between isentropic ozone fluxes and wave breaking events to understand the driving forces for isentropic transport.

Acknowledgments. The authors wish to thank Dr. Darryn Waugh for kindly providing the contour advection code and Dr. Robert Black and Dr. Mark Olsen for helpful discussions. We also thank the anonymous reviewers for their constructive comments on the paper. This work was supported by NASA Contracts NAG1-2202, NAS500171, and NAS1-96016. The DAO GEOS- 1 data were acquired from the Web site (http://eosdata.gsfc.nasa. gov/data/dataset/DAO/).

\section{REFERENCES}

Andrews, D. G., J. R. Holton, and C. B. Leovy, 1987: Middle Atmosphere Dynamics. Academic Press, 489 pp.

Appenzeller, C., H. C. Davies, and W. A. Norton, 1996: Fragmentation of stratospheric intrusions. J. Geophys. Res., 101, 1435-1456.

Baker, M. N., and D. M. Cunnold, 2001: On the uses and limitations of contour advection as a technique for understanding vortex dynamics. J. Atmos. Sci., 58, 2210-2221.
Beekmann, M., and Coauthors, 1997: Stratosphere-troposphere exchange: Regional and global tropopause folding occurrence. Tropospheric Ozone Research, O. Hov, Ed., Transport and Chemical Transformation of Pollutants in the Troposphere, Vol. 6, Springer-Verlag, 131-151.

Chameides, W. L., and J. C. G. Walker, 1973: A photochemical theory of tropospheric ozone. J. Geophys. Res., 78, 8751-8760.

Chen, P., 1995: Isentropic cross-tropopause mass exchange in the extratropics. J. Geophys. Res., 100, 16 661-16 673.

Crutzen, P. J., 1973: A discussion of the chemistry of some minor constituents in the stratosphere and troposphere. Pure Appl. Geophys., 106, 1385-1399.

1995: Ozone in the troposphere. Composition, Chemistry, and Climate of the Atmosphere, H. B. Singh, Ed., Van NostrandReinhold, 349-393.

Danielson, E. F., 1968: Stratospheric-tropospheric exchange based on radioactivity, ozone and potential vorticity. J. Atmos. Sci., 25, 502-518.

—_, R. S. Hipskind, S. E. Gaines, G. W. Sachse, G. L. Gregory, and G. F. Hill, 1987: 3-dimensional analysis of potential vorticity associated with tropopause folds and observed variations of ozone and carbon monoxide. J. Geophys. Res., 92, 2103-2111.

Davis, D. D., and Coauthors, 1996: Assessment of ozone photochemistry in the western North Pacific as inferred from PEMWest A observations during the fall 1991. J. Geophys. Res., 101, 2111-2134.

Dethof, A., A. O'Neill, and J. M. Slingo, 2000a: Quantification of the isentropic mass transport across the dynamical tropopause. J. Geophys. Res., 105, 12 279-12 293.

$\ldots, \ldots, \ldots$, and P. Berrisford, 2000b: Quantification of isentropic water vapor transport into the lower stratosphere. Quart. J. Roy. Meteor. Soc., 126, 1771-1788.

Edouard, S., R. Vautard, and G. Brunet, 1997: On the maintenance of potential vorticity in isentropic coordinates. Quart. J. Roy. Meteor. Soc., 123, 2069-2094.

Emmons, L. K., and Coauthors, 2003: Budget of tropospheric ozone during TOPSE from two chemical transport models. J. Geophys. Res., 108, 8372, doi:10.1029/2002JD002665.

Follows, M. J., and J. F. Austin, 1992: A zonal average model of the stratospheric contributions to the tropospheric ozone budget. $J$. Geophys. Res., 97, 18 047-18 060.

Gidel, L. T., and M. A. Shapiro, 1980: General circulation model estimates of the net vertical flux of ozone in the lower stratosphere and the implications for the tropospheric ozone budget. J. Geophys. Res., 85, 4049-4058.

Haynes, P., and E. Shuckburgh, 2000: Effective diffusivity as a diagnostic of atmospheric transport. Part II: Troposphere and lower stratosphere. J. Geophys. Res., 105, 22 795-22 810.

Hoerling, M. P., T. K. Schaack, and A. J. Lenzen, 1991: Global objective tropopause analysis. Mon. Wea. Rev., 119, 1816-1831.

Holton, J. R., P. H. Haynes, M. E. McIntyre, A. R. Douglass, R. B. Rood, and L. Pfister, 1995: Stratosphere-troposphere exchange. Rev. Geophys., 33, 403-439.

Hoskins, B. J., 1991: Towards a PV- $\theta$ view of the general circulation. Tellus, 43AB, 27-35.

Houghton, J. T., Y. Ding, D. J. Griggs, M. Noguer, P. J. van der Linden, and D. Xiaosu, 2001: Climate Change 2001: The Scientific Basis-Contribution of Working Group I to the Third Assessment Report of IPCC. Cambridge University Press, 944 pp.

Junge, C. E., 1962: Global ozone budget and exchange between stratosphere and troposphere. Tellus, 14, 363-377.

Lamarque, J.-F., P. G. Hess, and X. X. Xie, 1999: Three-dimensional model study of the influence of stratosphere-troposphere exchange and its distribution on tropospheric chemistry. J. Geophys. Res., 104, 26 363-26 372.

Lelieveld, J., and F. J. Dentener, 2000: What controls tropospheric ozone? J. Geophys. Res., 105, 3531-3551.

Levy, H., P. S. Kasibhatla, W. J. Moxim, A. A. Klonecki, A. I. Hirsch, S. J. Oltmans, and W. L. Chameides, 1997: The global impact 
of human activity on tropospheric ozone. Geophys. Res. Lett., 24, 791-794.

Liu, S. C., M. Trainer, F. C. Fehsenfeld, D. D. Parrish, E. J. Williams, D. W. Fahey, G. Hübler, and P. C. Murphy, 1987: Ozone production in the rural troposphere and the implications for regional and global ozone distributions. J. Geophys. Res., 92, 4191-4207.

Morgenstern, O., and A. Marenco, 2000: Wintertime climatology of MOZAIC ozone based on the potential vorticity and ozone analogy. J. Geophys. Res., 105, 15 481-15 493.

— port and ozone in the upper troposphere and lower stratosphere region. J. Geophys. Res., 106, 10 205-10 221.

Müller, J. F., and G. P. Brasseur, 1995: IMAGES: A 3-dimensional chemical transport model of the global troposphere. J. Geophys. Res., 100, $16445-16490$.

Murphy, D. M., and D. W. Fahey, 1994: An estimate of the flux of stratospheric reactive nitrogen and ozone in the troposphere. $J$. Geophys. Res., 99, 5325-5332.

Norton, W. A., 1994: Breaking Rossby waves in a model stratosphere diagnosed by a vortex-following coordinate system and a technique for advecting material contours. J. Atmos. Sci., 51, 654673.

Olsen, M. A., A. R. Douglass, and M. R. Schoeberl, 2002: Estimating downward cross-tropopause ozone flux using column ozone and potential vorticity. J. Geophys. Res., 107, 4636, doi:10.1029/ 2001JD002041.

— — - and - 2003: A comparison of Northern and Southern Hemisphere cross-tropopause ozone flux. Geophys. Res. Lett., 30, 1412, doi:10.1029/2002GL016538.

Postel, A. P., and M. H. Hitchman, 1999: A climatology of Rossby wave breaking along the subtropical tropopause. J. Atmos. Sci., 56, 359-373.
Roelofs, G.-J., and J. Lelieveld, 1997: Model study of the influence of cross-tropopause $\mathrm{O}_{3}$ transports on tropospheric $\mathrm{O}_{3}$ levels. Tellus, B49, 38-55.

Schubert, S. D., R. B. Rood, and J. Pfaendtner, 1993: An assimilated dataset for earth science applications. Bull. Amer. Meteor. Soc., 74, 2331-2342.

Scott, R. K., and J.-P. Cammas, 2002: Wave breaking and mixing at the subtropical tropopause. J. Atmos. Sci., 59, 2347-2361.

Shepherd, T. G., J. N. Koshyk, and N. Ngan, 2000: On the nature of large-scale mixing in the stratosphere and mesosphere. J. Geophys. Res., 105, $12433-12446$.

Wang, H.-J., D. M. Cunnold, L. W. Thomason, J. M. Zawodny, and G. E. Bodeker, 2002: Assessment of SAGE version 6.1 ozone data quality. J. Geophys. Res., 107, 4691, doi:10.1029/ 2002JD002418.

Wang, P. H., D. M. Cunnold, J. M. Zawodny, R. B. Pierce, J. R. Olson, G. S. Kent, and K. M. Skeens, 1998a: Seasonal ozone variations in the isentropic layer between 330 and $380 \mathrm{~K}$ as observed by SAGE II: Implication of extratropical cross-tropopause transport. J. Geophys. Res., 103, 28 647-28 659.

Wang, Y., D. J. Jacob, and J. A. Logan, 1998b: Global simulation of tropospheric $\mathrm{O}_{3}-\mathrm{NO}_{\mathrm{x}}-\mathrm{Hydrocarbon}$ chemistry. 3. Origin of tropospheric ozone and effects of nonmethane hydrocarbons. $J$. Geophys. Res., 103, $10757-10767$.

Waugh, D. W., and R. A. Plumb, 1994: Contour advection with surgery: A technique for investigating finescale structure in tracer transport. J. Atmos. Sci., 51, 530-540.

Zachariasse, M., P. F. J. van Velthoven, H. G. J. Smit, J. Lelieveld, T. K. Mandal, and H. Kelder, 2000: Influence of stratospheretroposphere exchange on tropospheric ozone over the tropical Indian Ocean during the winter monsoon. J. Geophys. Res., 105, $15403-15416$. 